\title{
The Last Monks of Worcester Cathedral Priory
}

\author{
David E. Thornton \\ History Department, Bilkent University, Ankara 06800, Turkey
}

\begin{abstract}
This paper traces the history of the Benedictine community of St Mary's Cathedral Priory, Worcester, from 1534 until its surrender in 1540, with the aim of determining the number and identity of the monks of Worcester at the time of the dissolution. No deed of surrender survives for the priory that would record the names of the monks, and it is argued here that previous studies have underestimated the size of the conventual community during its final days. Using pension lists as well as a hitherto unstudied document preserved in Bishop Bell's Liber Visitationis, a more accurate figure for the convent can be offered and the fortunes of many of the monks in the years after the dissolution determined.
\end{abstract}

\section{KEYWORDS}

Medieval monasticism;

Benedictine monks;

Worcester Cathedral Priory;

the Dissolution

It has often been stated that membership of the religious orders in England and Wales decreased significantly during the 1530 s, largely because of the events that culminated in the dissolution of the monasteries. ${ }^{1}$ However, the extent to which numbers may have been in decline before Henry VIII and his vicegerent in spiritual matters, Thomas Cromwell, began surveying and bullying the religious houses during the second half of the decade is a matter that requires closer scholarly scrutiny: for example, was there already a reduction in vocations, symptomatic of the alleged degenerate condition of many monasteries as described by the king's commissioners in 1536-7, or was the decline simply a result of the final dissolutions during the last few years of the decade? The accuracy of statistics drawn from the extant deeds of surrender and records of monastic pensions from the period 1538-40 in particular may yet be questioned in the light of a thorough re-examination of the relevant documents. ${ }^{2}$ This paper considers in detail the final years of St Mary's Cathedral Priory, Worcester, and argues that, although there is indeed evidence of a reduction in the size of the Benedictine community when the priory was surrendered in 1540, hitherto unstudied material indicates that this reduction was not as marked as previous historians have suggested.

\footnotetext{
CONTACT David E. Thornton tdavid@bilkent.edu.tr

${ }^{1}$ For example, D. Knowles and R. N. Hadcock, Medieval Religious Houses. England and Wales, 2nd edn (London: Longmans, 1971), pp. 47, 488; J. C. Russell, 'The Clerical Population of Medieval England', Traditio, 2 (1944), 177-212.

${ }^{2}$ d discuss these issues more generally in a forthcoming paper, 'The Prosopography of English Monastic Orders at the Dissolution: Evidence from the National Archives Assessed' in Archives: The Journal of the British Records Association (scheduled for Spring 2019).
} 
The Cathedral Priory at Worcester was among the last monasteries to be dissolved, lasting until mid-January 1540. Thus, the relevant entry in the so-called 'Worcester Chronicle' reads as follows:

In that monethe all religiouse men, as the monkes, friers, and Channons, chaynged theyr habittes of religion and wore secular mens rayment, videlicet gownes Jackettes, close hosen etc. And certen were expulsed out of the place [Worcester Cathedral Priory], and the priorie was then named a Colledge. And the 4 bells in the leden steple were this yeare taken downe, broken in pieces, and carried away, ${ }^{3}$

The formal surrender of the cathedral priory by prior Henry Holbeach, ${ }^{4}$ and the convent to representatives of the government of Henry VIII brought to an end almost nine centuries of monastic life in the city, and within two years St Mary's had been re-founded as a cathedral chapter of secular canons. Despite the high rate of preservation of documents for the priory in the late medieval and early Tudor periods, especially when compared to other religious houses, the question of the number and identity of the monks who remained at the priory on the day of its dissolution is somewhat difficult to answer with any exactness, because the deed of surrender is no longer extant. Writing over a century ago, Arthur Leach stated that Prior Holbeach and thirty-three monks surrendered to the Crown, ${ }^{5}$ though he cited no source for this figure. More recently, Joan Greatrex has suggested in her monumental Biographical Register of the English Cathedral Priories that 'only seventeen or eighteen' monks of Worcester were left in January 1540, adding rather poetically that 'the soul of Worcester Cathedral Priory had departed before the body was removed.' ${ }^{6}$ Greatrex acknowledges that the surrender deed is missing, but adds that 'the names are provided by the pension lists.'

This is indeed a sorry state of affairs for a religious community that had numbered as many as fifty in the late eleventh century and, despite an inevitable decline following the Black Death, had maintained up to forty monks during the fifteenth and early sixteenth centuries. However, a decline in the size of the religious community at Worcester during the late 1530s would not be without precedent: Josiah Cox Russell, in his study of the clerical population of medieval England, pointed out that, for the Benedictine order overall, there was a drop in numbers from the late fifteenth century and especially during the 1530s: 'Even in the last decade membership fell off badly, probably as much as twenty to thirty per cent.' ${ }^{8}$ Russell's estimate would agree more or less with Leach's figure, but certainly not with that offered by Greatrex. The purpose of this paper is to examine whether the community of Worcester Cathedral Priory did in fact decline so significantly during the 1530 s and to determine therefore, who were the last monks of Worcester.

Since the surrender deed for Worcester Cathedral Priory does not survive, there is no single document now extant that explicitly names all the brethren on the day of priory's dissolution. However, membership of the community can be reconstructed by combining

3D. MacCulloch and P. Hughes, 'A Bailiff's List and Chronicle from Worcester', The Antiquaries Journal, 75 (1995), 235-53, at 244; also D. MacCulloch, 'Worcester: A Cathedral City in the Reformation', in The Reformation in English Towns, 1500-1640, ed. by P. Collinson and J. Craig (Cambridge: Macmillan Press, 1998), pp. 94-112, at p. 100.

${ }^{4} \mathrm{As}$ is discussed below, most of the 'surnames' borne by Worcester monks were probably derived from the names of their places of origin. Consequently, I will spell these toponymic surnames according to the modern spelling of the place-names in question, where apparent.

${ }^{5}$ A. F. Leach, Documents illustrating Early Education in Worcester. 685 to 1700 (Worcestershire Historical Society, 1913), Ivi.

${ }^{6} \mathrm{~J}$. G. Greatrex, Biographical Register of the English Cathedral Priories of the Province of Canterbury, c. 1066-1540 (Oxford: Oxford University Press/Clarendon Press, 1997) [hereafter BRECP], p. 761.

${ }^{7} B R E C P$, p. 761, n. 55.

${ }^{8}$ Russell, p. 188; compare this with the figures cited by Knowles and Hadcock, pp. 488-95. 
Table 1. Monks of Worcester in 1534.

\begin{tabular}{|c|c|c|c|c|c|c|c|}
\hline 1 & $\begin{array}{l}\text { Willelmus More } \\
\text { prior }\end{array}$ & 18 & Roger Battnall' & 31 & Nicolaus Shypystun & 35 & John'More \\
\hline 2 & $\begin{array}{l}\text { Johannes Lawerne } \\
\text { subprior }\end{array}$ & 19 & Thomas Blockeley' & 32 & Johannes Blackwell & 46 & Thomas Brodwas \\
\hline 3 & Rogerus Nechkam & 20 & Edmundus Ledburi & 33 & $\begin{array}{l}\text { Bartholomeus } \\
\text { Stoke }\end{array}$ & 37 & Robart Gregori \\
\hline 4 & $\begin{array}{l}\text { Willelmus Hoding- } \\
\text { ton elemosinarus }\end{array}$ & 21 & Thomas Wlstane & 34 & Johannes Crowle & 38 & John' Copthohrne \\
\hline 5 & $\begin{array}{l}\text { Thomas Sudburi } \\
\text { cellararius }\end{array}$ & 22 & Wyllyam Hanbury & & & 39 & $\begin{array}{l}\text { Henricus Hymmul- } \\
\text { ton }\end{array}$ \\
\hline 6 & Humfrey Grafton & 23 & Rycardus Halow & & & 40 & Johannes Hardwyke \\
\hline 7 & Willelmus Lemster & 24 & Rogerus Beydylley & & & 41 & Thomas Oswalde \\
\hline 8 & Johannes Musard & 25 & Thomas Grymeley & & & & \\
\hline 9 & Rogerus Stanford & 26 & William Bordysley & & & & \\
\hline 10 & Ricardus Calaman & 27 & Willelmus Benett & & & & \\
\hline 11 & Willelmus Fordam & 28 & Hugo Bromsgrove & & & & \\
\hline 12 & Johanes Berow & 29 & Wyllyam Wolverley & & & & \\
\hline 13 & Thomas Sturbyrg & 30 & Johannes Newnam & & & & \\
\hline 14 & Ricardus Clyve & & & & & & \\
\hline 15 & Wyllelmus Wyche & & & & & & \\
\hline 16 & Johannes Multon' & & & & & & \\
\hline 17 & Humfridus Webley & & & & & & \\
\hline
\end{tabular}

the testimony of other sources dating from both before and after January 1540, and it is argued that the number of monks was higher than both Greatrex's figure and even Leach's less pessimistic estimate. We will start therefore with a document in The National Archives, dated 17 August 1534, which contains the original signatures of the prior, at that time William More, and forty monks, arranged in four unequal columns, indicating that they had taken the Oath of Supremacy. ${ }^{9}$ By the Act of Supremacy of that year, all members of the clergy in England and Wales were required to swear an oath acknowledging that Henry VIII was supreme head of the Church in England. ${ }^{10}$ Table 1 reproduces the columnar layout of the list of signatures, with sequential numbers added. It seems likely that this list of forty monks plus the prior is an accurate representation of the Worcester community as it stood in 1534. A list of members of the convent from just a few years earlier (1531/2) gives the prior plus thirty-nine monks, which is a similar total. ${ }^{11}$ Furthermore, there are, to my knowledge, no monks of Worcester who did not sign this document and yet are named in other sources from both before and after August $1534 .^{12}$

Of the forty-one members of Worcester Cathedral Priory in the summer of that year, it is interesting to note that the majority bore surnames that are toponymic in character, that is they are derived from place-names. At least thirty-three ( 80 per cent) had such a surname,

${ }^{9}$ The National Archives [hereafter TNA], E25/122/3; Annual Report of the Deputy Keeper of the Public Records (London: H.M. Stationary Office, 1840- ), VII, App. II, 305. There are a few mistakes in the printed version, so name-forms are given here according to the original; most abbreviations silently expanded.

${ }^{10}$ For the role of oaths in the Henrician Reformation, see J. M. Gray, Oaths and the English Reformation (Cambridge: Cambridge University Press, 2013).

${ }^{11}$ Worcester Cathedral Library [hereafter WCL], Reg. A.12, fo. 135r-v; see also the same manuscript at fo. 125r (1525/6) and the slightly shorter list in Lambeth Palace Library, Register of Archbishop Warham, volume Il, fo. 293v (1521).

${ }^{12}$ Two relatively young Worcester monks, William Overbury and William Webley, who were both ordained as priest in June 1527 , are absent in 1534, but both can be readily explained away. Overbury transferred to the Benedictine house at Winchcombe, Gloucestershire, later in 1527, and therefore appears acknowledging the royal supremacy as third prior of Winchcombe in 1534. Secondly, the surname Webley is probably in fact a misreading of Woluerley, as a brother William Wolverley - who does occur in the 1534 list - had been ordained subdeacon in 1525 and deacon in 1526/7, and a'William Webley' is otherwise undocumented. See Worcestershire Record Office (now Worcestershire Archive and Archaeology Service) [hereafter WRO] MS. b706.093-BA2648/9(i), p. 164; BRECP, 860, 889, 894. 
or even thirty-five if we include the two cases of the name More, which could alternatively be topographical in origin. It has been suggested that such toponymic surnames were assumed by members of monastic orders in late medieval England on entering a religious house and indicated the place of birth or recent origin of their respective bearers. ${ }^{13}$ If this is the case, then as many as twenty-two of these monks of Worcester had monastic toponyms derived from local places where the priory itself held property. For example, John Lawerne, subprior in 1534, possibly hailed from Laughern in Worcestershire where the priory had a chapel and the manor; and even brother Bartholomew Stoke, whose surname was certainly very common as a placename throughout England, may have been associated with Stoke Prior, Worcestershire, where the priory also had both temporal and spiritual property. ${ }^{14}$ Of those monks whose surnames were not toponymic, four bore the names of saints: two local, Wulfstan and Oswald, as well as Bennett (for Benedict, founder of the Order), and Gregory. Such saintly monastic surnames, or 'hagionyms', were increasingly used by monks instead of toponyms during the late fifteenth and early sixteenth centuries. ${ }^{15}$ The remaining two monks' surnames - Musard and Calaman - are both of apparent non-English origin. Musard is French and is attested in England after the Conquest, but had also been borne by a monk of Worcester in the fifteenth century, ${ }^{16}$ as well as by a monk of Evesham and a canon of Studley in the fourteenth. The origin of the surname Calaman is more obscure. ${ }^{17}$

The list of signatories of the oath of supremacy is a useful and accurate starting point for examining the fate of the monastic community at Worcester half a decade later. A number of months before the Act of Supremacy was passed and enacted, parliament had passed another act, 25 Henry VIII c. 21, which transferred the right to grant dispensations from the papal penitentiary to the archbishop of Canterbury. ${ }^{18}$ Thus, from the spring of 1534 onwards, any male cleric wishing to be ordained below the canonical age was obliged to apply to the newly established Faculty Office for dispensations. The same was true for regular clergy who requested a capacity 'to change their habit' in order to leave religion altogether or, for members of male religious orders, to hold offices as secular priests; and the extant Faculty Office Register testifies that many religious did so during the late 1530 s. ${ }^{19}$ One such a request is recorded in a letter sent by Worcester monk Roger Neckham to Thomas Cromwell, as Henry VIII's vicegerent in spiritual matters, dated 11 November 1535, in which he states

${ }^{13}$ D. Knowles, The Religious Orders in England, 3 vols (Cambridge: Cambridge University Press, 1948-59), II, p. 231; J. G. Greatrex, 'The Local Origins of the Monks of Worcester Cathedral Priory', Transactions of the Worcestershire Archaeological Society, 3rd Series, 16 (1998), 143-53.

${ }^{14}$ Battenhall (manor); Berrow (chapel, manor); Blackwell (manor); Broadwas (church, manor); Bromsgrove (church and manor); Cleeve Prior (church manor); Cropthorne (chapel, church, manor); Crowle (manor); Grafton (chapel); Hallow (chapel, manor); Hardwick (manor); Himbleton (chapel church manor); Laughern (chapel, manor); Moor (manor); Newnham (manor); Old Sodbury, Gloucs. (church); Shipston super Stour, (chapel, manor); Stoke Prior (church, manor); Wick Episcopi (chapel); Wolverley (church, manor). See M. Jurkowski, N. Ramsay and S. Renton, English Monastic Estates, 1066-1540: A List of Manors, Churches and Chapels (Kew: List and Index Society, 2007), pp. 559-63.

${ }^{15}$ Knowles, Religious Orders, II, p. 231.

${ }^{16}$ Thomas Musard was ordained acolyte in 1408-9 and was prior of Worcester between 1458 and 1469: WRO b706.093BA2648/5(ii), p. 175; D. M. Smith, The Heads of Religious Houses: England \& Wales, III. 1377-1540 (Cambridge: Cambridge University Press, 2008), p. 87; BRECP, p. 853.

${ }^{17}$ For this surname, forms include, in order of frequency, Calaman and Calamon, Kalaman and Coleman. Possible derivations from the Irish saint's name Colmán, seem unlikely, but would of course fit with hagionymic surnames like Wulfstan. Note that one Benedict Calaman, and his wife Antonia, are recorded as non-householders living in Bishopsgate, London, for 1483 in TNA E179/242/25, m. 10, where they are said to be from 'India': see the England's Immigrants 1330 - 1550 database, Version 1.0, at <http://www.englandsimmigrants.com/person/31179>, accessed on 6 March 2018.

${ }^{18}$ P. D. Clarke, 'Canterbury as the New Rome: Dispensations and Henry VIII's Reformation', Journal of Ecclesiastical History, 64/1 (2013), 20-44; D. S. Chambers (ed.), Faculty Office Register 1534-1549 (Oxford: Clarendon Press, 1966).

${ }^{19} \mathrm{G}$. A. J. Hodgett, 'The Unpensioned Ex-Religious in Tudor England', Journal of Ecclesiastical History, 13 (1962), 195-202; F. D. Logan, Runaway Religious in Medieval England, c. 1240-1540 (Cambridge: Cambridge University Press, 1996), pp. $159-60$. 
that his confrere Hugh Bromsgrove wishes to obtain a capacity and 'desyryth a gyft of a benefice by owre monastery. ${ }^{20}$ Brother Hugh had been a member of the Worcester community since at least 1521, though no record of his admission or ordination as a monk of Worcester appears to have survived. ${ }^{21}$ Whether the requested capacity was in fact granted is not clear, though Neckham does not seem to offer any objections: 'he ys mynded thys to departe the monastery wythowte eny cryme or fawte that shulde move hym to so departe'. If it was, then Bromsgrove would have left Worcester Cathedral Priory in late 1535 or early 1536, and indeed his name does not occur in any subsequent documents. The conventual community probably numbered 39 monks plus the prior at the start of 1536 .

The exact circumstances and reasons for Hugh Bromsgrove's departure from St Mary's are not explicitly stated in the letter, yet it should be stressed that the years 1535-6 were in fact difficult and tumultuous ones for the priory. Although, as a relatively large and wealthy house, the Worcester Cathedral Priory was never under threat during the suppression of smaller religious houses in 1536-7, it did experience a number of serious internal disputes that no doubt undermined conventual solidarity as well as individual vocation. These disputes, as we shall see, seem to have led to the departure of a handful of members of the community, though that of Hugh Bromsgrove may have been unconnected. However, Greatrex goes so far as to claim that in 1536 alone, 'there was an exodus of some fifteen monks in addition to the two who left prior to the "election" [of Prior Holbeach], and several more were lost to sight soon after' (my italics) but offers no documentary evidence in support of this statement. Furthermore, to emphasize the point, she adds that when Hugh Latimer, bishop of Worcester, made an episcopal visitation of the priory in 1537, he 'encountered an already depleted chapter'. In fact, Latimer's injunctions for 1537 do not in fact refer to the size of the monastic community, whether in absolute or relative terms, though they do, as we might expect from a reformer such as Latimer, draw attention to the ignorance and negligence of divers religious persons in this monastery.' ${ }^{22}$ What happened at the priory in 1535-6 exactly, and how did these events affect the size of its monastic community?

A central figure in these events appears to have been the old prior, William More, alias Peters. A member of the community since the late 1480s and prior since 1518 More must have been in his mid-sixties at least by 1534 and is relatively well known, not to say infamous, due to the survival of his so-called 'Journal.' ${ }^{23}$ The latter is in fact an account book and has been partly responsible for More's modern reputation as a negligent and fine-living superior. While he clearly did spend a significant part of his time at manorial residences rather than at the monastery with his brethren, it seems likely that he was not so different from other religious superiors of the age. ${ }^{24}$ Yet, things were certainly not always running smoothly during the latter part of his priorate, as evidenced by successive visitations and resulting injunctions by Cardinal Wolsey (1525-6), Archbishop Cranmer (1534) and Bishop

\footnotetext{
${ }^{20}$ TNA SP 1/99, fo. 33; J. S. Brewer et al., Letters and Papers, Foreign and Domestic, of the Reign of Henry VIII, 36 vols (London: H. M. Stationery Office, 1862-1932) [hereafter $L P$ ], IX, no. 807.

${ }^{21} B R E C P$, p. 782.

${ }^{22}$ W. H. Frere and W. P. M. Kennedy, ed., Visitation Articles and Injunctions, 3 vols (London: Longmans, Green \& Co., 1910), II, p. 12.

${ }^{23}$ E. S. Fegan, ed., Journal of Prior William More (Worcestershire Historical Society, 1913-14). For More, see Knowles, Religious Orders in England, III, pp. 108-26; BRECP, pp. 848-50; A. Marett-Crosby, 'More, William (1471/2-1552)', in Oxford Dictionary of National Biography (Oxford: Oxford University Press, 2004) <http://www.oxforddnb.com/view/article/19196> [accessed 3 January 2018].

${ }^{24} \mathrm{M}$. Heale, The Abbots and Priors of Late Medieval and Reformation England (Oxford: Oxford University Press, 2016).
} 
Latimer (1537); and, the prior should probably take some of the responsibility at least. ${ }^{25}$ Correspondence survives among the State Papers, including many letters sent by individual monks to Thomas Cromwell, that highlights significant divisions within the Worcester monastic community by 1535-6: on the one side, we appear to have the prior and a majority of the brethren; on the other, stood a smaller but senior and influential group including Thomas Fordham, who had been deprived of the office of cellarer by Prior More a few years earlier, the aforementioned Dr. Roger Neckham who had lost the office of subprior, ${ }^{26}$ and John Musard who may have fallen foul of the prior by 1531 when he had allegedly stolen 'certain plate \& other things. ${ }^{27}$ The events have been reconstructed and discussed by Geoffrey Elton, among others, and need not be recounted in detail here. ${ }^{28}$ Archbishop Cranmer had made a visitation of the priory between 17 and 20 August 1534, and his subsequent injunctions, dated 22 February 1535, required the resolution of ongoing opposition within the community to Fordham's replacement as cellarer, Thomas Sudbury. ${ }^{29}$ Prior More was apparently unable to fulfil this particular injunction, for later in the year, on 21 October, a letter was sent to Cromwell, signed by twenty-seven members of the Worcester convent, venturing support for Sudbury and criticizing Fordham. ${ }^{30}$ None of the names in this admittedly incomplete list of Worcester brethren are previously unattested, supporting the suggestion above that no new monks had been admitted since the signing of the Oath of Supremacy more than a year earlier. In addition to the twenty-seven names, we can probably count Prior More and of course Sudbury himself among the opponents of Fordham, to which we might also add Richard Cleeve (Clive) as he appears subsequently as a supporter of the prior (see below). ${ }^{31}$ This would leave eleven monks from 1534 as supporters of Fordham, including Hugh Bromsgrove whose request for a capacity quoted above is dated a month later. These figures are confirmed by a statement, attributed to the prior in a later letter by Neckham, to the effect that 'if $\mathrm{x}$ or xi were out of the king's monastery he [More] could live quietly with all the remnant. ${ }^{32}$ Among those whose signatures are conspicuous by their absence in the letter of October 1535 and who, one may presume, were allies of Fordham et alii, are brothers John Berrow and Richard Calaman. These two monks were contemporaries of Fordham, Neckham and Musard, insofar as they were all admitted around the same time

\footnotetext{
${ }^{25}$ Frere and Kennedy, II, pp. 12, 14; J. M. Wilson, 'Cardinal Wolsey's Visitation of Worcester Cathedral Priory, 1526', English Historical Review, 40 (1925), 87-92; J. M. Wilson, 'Wolsey's and Cranmer's Visitations of the Priory of Worcester', English Historical Review, 41 (1926), 418-23; and more recently, S. Hobbs, 'Worcester Priory's Pre-Reformation Visitations', in Worcester Cathedral and Archive Blog, 3 Feb. 2016, <https://worcestercathedrallibrary.wordpress.com/2016/02/03/ worcester-priorys-pre-reformation-visitations/> [accessed 3 January 2018].

${ }^{26} B R E C P$, p. 855, implies that Neckham's removal by More from the office of subprior may have occurred in 1535 ('presumably before the visitation of royal commissioners'), and Greatrex cites John Musard's letter of 8 August of that year, in which he refers to this: $L P, I X, 52 / 2$. However, it seems likely that Neckham had been removed from office earlier. In the same sentence, Musard also mentions the removal of Thomas Fordham from the office of cellarer, which must have taken place around 1528-9 (BRECP, 807, 881), and Cardinal Wolsey's injunctions dated 3 November 1526 mention the destitutionem et remotionem supprioris cellerarii et duorum scholasticorum (Wilson, 'Cardinal Wolsey's Visitation', 90), presumably referring to the same events. Furthermore, the latest extant notice of Neckham as subprior is dated 23 June 1523, and from 1534 until at least late 1536 the office was held by John Laughern: BRECP, pp. 831, 855.

${ }^{27}$ Fegan, 331.

${ }^{28} \mathrm{G}$. R. Elton, Policy and Police: The Enforcement of the Reformation in the Age of Thomas Cromwell (Cambridge: Cambridge University Press, 1985), pp. 124-8; and Knowles, Religious Orders, III, 342-5.

${ }^{29}$ Wilson, 'Wolsey's and Cranmer's Visitations', 423.

${ }^{30}$ TNA SP $1 / 98$, fos 50-1; LP, IX, no. 653.

${ }^{31}$ Richard Cleeve is an interesting character. He had joined the Worcester community in the early 1500s (he was ordained priest in 1509) and in April 1524 there are records of his transfer to the Cluniac priory at nearby Dudley: WRO b706.093BA2648/8(i), p. 301; WCL Reg A.6(ii), fo. 143v. However, this move was evidently not permanent since, as we have seen above, he was again listed among the Worcester brethren in 1534.

${ }^{32}$ TNA SP $1 / 102 ; L P, X$, p. 119 (no. 311).
} 
and we can trace all five men being ordained collectively as a group, or cohort, in 1504 and later. ${ }^{33}$ Similarly, three other monks missing from the twenty-seven signatories - John Blackwell, Richard Hallow and William Wolverley - were also more or less contemporaneous with each other and were all ordained around $1525-7 .{ }^{34}$ It is possible therefore that, having been thrown together at the earliest stage of their careers at the cathedral priory, these two groups of monks formed friendships which at least in part influenced their interactions within the community subsequently.

The events of 1535-6 at Worcester involved the imprisonment of John Musard and the eventual incarceration of Prior More himself, probably at St Peter's Abbey, Gloucester, and of his ally Richard Cleeve. Following a brief return to the priory in early 1536 More had resigned as prior by March 'possibly under pressure. ${ }^{35}$ The task of finding a replacement for William More fell to Cromwell as vicegerent. More's eventual successor was not an existing member of the Worcester community, but an external appointee: Dr Henry Holbeach (Holbeche), alias Rands, a monk of Crowland Abbey, Lincs. ${ }^{36}$ While the decision to appoint an outside candidate rather than leave the members of the convent to elect one of their own may well have been a wise one, given the doubtlessly continuing acrimonious atmosphere at the priory, the control of the appointment of superiors by Cromwell during this period often selecting outsiders like Holbeach - was in fact a recurring feature of abbatial elections during this period. ${ }^{37}$ However, the election has been described as 'illegitimate' and 'a farce' by Greatrex. ${ }^{38}$ The account of the election in the relevant priory register, dated 23 March 1536, records the names of thirty four monks though the version printed by John Noake only gives thirty three, omitting William Leominster who was in fact named though not physically present and voted by proxy ('per proccuratorem'). ${ }^{39}$ Yet again, there are no previously unattested names, so it is unlikely that there had been any recent admissions to the community. More significantly for present purposes, the number of monks listed by Noake corresponds to Leach's figure, cited at the start of this paper, for the size of the Worcester monastic community at its dissolution four years later, and it is likely that Leach based his statement on this source. However, there is evidence that neither thirty three, nor the more accurate thirty four represents the total size of the convent at the time of Holbeach's election. There are a number of monks lacking in this list who are attested later: for instance, Brothers Bartholomew Stoke and the Richard Cleeve who would both be described as monks of Worcester in receipt of pensions in January 1540. Furthermore, Cleeve's erstwhile enemy John Musard is also missing. We know that he was still in prison a month and a half before the election of Holbeach, for on 31 January 1536 he wrote a letter to Cromwell entitled The decays of your honorable Lordship's monastery at Worcettur, and the occasion thereof in which he complained of his conditions and begged Cromwell 'to be mercyfull as far as to remove me fro the tyranny of my untrue master, unto Westminster, where y wold gladly yend my

${ }^{33}$ WRO, b706.093-BA2648/8(i), pp. 287, 289, 299; BRECP, pp. 807, 849, 854. On the admission and ordination of groups of monks, see below, 14 .

${ }^{34}$ A. T. Bannister, ed., Registrum Caroli Bothe, Episcopi Herefordensis, A.D. MDXVI-MDXXXV (London: Canterbury and York Society, 1921), p. 320; WRO b706.093-BA2648/7(ii), pp. 163, 186.

${ }^{35}$ Elton, p. 128; LP, X, p. 8 (no. 597). William More was pensioned and settled on the priory's manor at Grimley, Worcs., or (alternatively) at Crowle:TNA SP 1/104, fo. 275; LP, X, p. 536 (no. 1272); Knowles, Religious Orders, III, p. 344. He died in 1552.

${ }^{36} B R E C P$, p. 824; M. Bowker, 'Holbeach, Henry (d. 1551)', in Oxford Dictionary of National Biography (Oxford: Oxford University Press, 2004); online edn, Jan 2008 <http://www.oxforddnb.com/view/article/13477> [accessed 3 January 2018].

${ }^{37}$ Heale, pp. 294-5.

${ }^{38}$ BRECP, pp. 761, 824.

${ }^{39}$ WCL Reg. A.6(iii), fos 1-2; J. Noake, The Monastery and Cathedral of Worcester (London: Longman \& Co., 1866), pp. $208-9$. 
lyfe q[uie]tlye yn the serves of almyghty god'. ${ }^{40}$ It seems unlikely that Cromwell agreed to this request to transfer to Westminster Abbey, for Musard does not occur among the monks of Westminster recorded by E. H Pearce, ${ }^{41}$ and, more significantly, two years later, in May 1538, the Faculty Office Register records that Musard, here called 'alias Walker', was granted a capacity to change his habit and is described as 'recently' of Worcester priory. ${ }^{42}$ Given the nature of Holbeach's election, it seems probable that the list of thirty four monks was not complete, and therefore is not necessarily a reliable indicator of the size of the monastic community in 1536, never mind in 1540.

Thus far, we have documentary evidence for the departure of only three members of the Worcester chapter before 1540: Hugh Bromsgrove (after November 1535), Prior More (by early March 1536) and John Musard (before May 1538). A couple of other monks may have left the community around the same time, but there is no evidence of the mass exodus of up to fifteen monks, as claimed by Greatrex. This brings us to January 1540 and the actual surrender of the Cathedral priory. Partly as a result of the sometimes violent response to the suppressions of 1536-7, the government followed a different policy in 1538-40, leaning on individual monasteries and encouraging them to 'voluntarily' surrender. Worcester Cathedral Priory was in fact among the last religious houses to be dissolved. The exact date of the dissolution of the priory has been a matter of some uncertainty because the original deed of surrender does not appear to have survived. Thus, older authorities such as Browne Willis and Valentine Green, cited 18 January 1540 as the date of surrender, ${ }^{43}$ and were followed in turn by Knowles and Hadcock. ${ }^{44}$ The earlier authors do not give a source for this date, but some also refer to a list of pensions of the same date, which is discussed in detail below. However, Noake gave the date of surrender as two days earlier, on 16 January 1540, and cites a short memorandum from a priory register as his source. ${ }^{45}$ The relevant entry reads:

The surrend'r of pe priory of Worcet'r. Mem. that the monastery \& priory of Worcet'r was surrenderd' \& gyff up by the priour and convent of the same howse [in] to the kynges handes Henry the Eyght the xvj daye of january upon Seynt Marcelles daye pe mart'r. In the yere of o'r lord mill'imo $\mathrm{CCCCC}^{\circ} . \mathrm{xl}^{\circ}$. And in the $\mathrm{xxxj}$ yere of the seyd kyng Henr' the Eyght. ${ }^{46}$

The relevant manuscript appears to be a compilation of various items, including material from the 1520s and 1530s. The memorandum itself however is unlikely to be a contemporary description of the surrender of the Cathedral Priory: it is immediately preceded on the page (fo. 170v) by brief summaries, written by the same hand, of two acts of Parliament from 1541 which suggest that it was written around the same time. ${ }^{47}$ Furthermore, it is interesting that the year ' 1540 ' is specified. Prior to the mid-eighteenth century, the new

\footnotetext{
${ }^{40} \mathrm{BL}$ Cotton MS Cleopatra E.IV, fo.116r; LP, X, p. 216 (no. 75).

${ }^{41} \mathrm{E}$. H. Pearce, The Monks of Westminster. Being a Register of the Brethren of the Convent from the Time of the Confessor to the Dissolution (Cambridge: Cambridge University Press, 1916).

${ }^{42}$ Chambers, p. 133.

${ }^{43}$ W. Dugdale, Monasticon Anglicanum: A History of the Abbies and Other Monasteries, Hospitals, Frieries, and Cathedral and Collegiate Churches, with their Dependencies, in England and Wales, ed. John Caley and others, 6 vols (London: Bohn, 1817-30), I, p. 581; B. Willis, An History of the Mitred Parliamentary Abbies, and Conventual Cathedral Churches, 2 vols (London: W. Bowyer, 1718), I, p. 311; V. Green, The History and Antiquities of the City and Suburbs of Worcester, 2 vols (London: V. and R. Green, 1796), I, p. 125.

${ }^{44}$ Knowles and Hadcock, p. 81.

${ }^{45}$ Noake, pp. xxviii, 229-30; also Noake, 'Worcester Monastery and Cathedral', The Gentleman's Magazine, 2 (1869), 30-46, at 46.

${ }^{46}$ WCL Reg. A.12, fo. 170v. I am extremely grateful to Dr David Morrison, Worcester Cathedral Library and Archive, for help with this manuscript.

${ }^{47}$ The relevant acts are 33 Hen. VIII c. 17 (Act for the Confirmation and Continuation of Certain Acts) and 33 Hen. VIII c. 9 (Unlawful Games Act).
} 
year was considered to start on 25 March, not 1 January as is prevalent today: hence, an original document dated January 1540 would in fact equate with January 1541 according to the 'new style' of dating. On the other hand, the regnal year ' 31 Henry VIII' (1539-40) is correct, giving 1540 for January. As for the day itself, the scribe probably did intend to write $x v j$, rather than $x v i i j$, as the feast day of St Marcellus, Pope and Martyr, is 16 January. ${ }^{48}$ It is at least possible therefore that the priory was surrendered on 16 January, not the 18th of the month. Indeed, for the surrender deeds of other religious houses for the period 1538-40 preserved in the National Archives as series TNA E322, ${ }^{49}$ the dates of surrender are earlier than the equivalent pension lists for the same religious houses, sometimes by a few days, often by a number of weeks: for instance, St Albans Abbey was surrendered on 5 December 1539 whereas the monks were assigned pensions nine days later on 14 December. ${ }^{50}$ In the case of Worcester therefore, the priory may well have been surrendered on 16 January, but the pensions were assigned two days later.

With the final dissolution of the monasteries during the years 1538-40, members of male religious houses were essentially faced with two options: former monks and canons - like nuns but unlike most ex-friars - could be assigned a pension by the royal government via the newly established Augmentation Offices, or occasionally by private individuals, to be paid until death; or, as secular priests, they could receive a position within the new Henrician ecclesiastical hierarchy and they could lose the pension or have it reduced, depending on the value and source of the benefice. ${ }^{51}$ In the case of former cathedral priories, like Worcester, or of abbeys now elevated to the status of cathedral, such as St Peter's Gloucester, a number of the ex-monks were kept on at the new secular establishments as canons, whereas others were deemed surplus to requirements and pensioned off. ${ }^{52}$

The names of the monks of Worcester Cathedral Priory at the time of its surrender, and their individual fate during the next few years can be reconstructed using a number of extant sources, including pension lists and documents from the new secular cathedral. These sources are considered in detail below, but a summary of their testimony is given in Table 2. The names in the table have been arranged in such a way as to display visually the relationship between the different documents and facilitate explanation of the arguments set forth below.

The earliest document is the list of pensions dated ' 18 January, 31 Henry VIII', that is, 1540, which gives the names of eleven ex-monks of Worcester who are described as 'divers superfluous persons late religious ... now despatched out of the same. ${ }^{53}$ The names of these ex-monks and their pensions are as follows in Table 3. Furthermore, a large bound manuscript in the National Archives from the Court of Augmentations (TNA E315/234), preserves copies of documents, detailing the pension arrangements

\footnotetext{
${ }^{48}$ D. H. Farmer, The Oxford Dictionary of Saints (Oxford: Oxford University Press, 2011), s.n. 'Marcellus (d. 309)'.

${ }^{49}$ Annual Report of the Deputy Keeper of the Public Records, VIII, 1847, Appendix II, pp. 5-51.

${ }^{50}$ TNA E322/208; TNA E315/234, fo. 63r; LP, XV, p. 547 (no. 1032).

${ }^{51}$ On pensions, see Knowles, Religious Orders, III, 404-8; G. Baskerville, English Monks and the Suppression of the Monasteries (New Haven: Yale University Press, 1936), pp. 186-93, 254-8; more recently, R. Clark,'The Regular Clergy of Derbyshire and the Dissolution of the Monasteries', Derbyshire Archaeological Journal, 109 (1989), 131-49, at 141-2; M. Glynn, 'The Payment of Pensions to the Ex-Religious of Tudor Bedfordshire', Midland History, 32/1 (2007), 41-67.

${ }^{52}$ Knowles, Religious Orders, III, 391-2; S. E. Lehmberg, The Reformation of Cathedrals. Cathedrals in English Society, 1485-1603 (Princeton NJ: Princeton University Press, 1988), pp. 81-4; G. Baskerville,'The Dispossessed Religious after the Suppression of the Monasteries', in Essays in History presented to Reginald Lane Poole, ed. by H. W. C. Davis (Oxford: Clarendon Press, 1927), pp. 436-65, at pp. 451-2.

${ }^{53}$ TNA E315/245, fo. 8r; LP, XV, p. 27 (no. 81).
} 
Table 2. The Last Monks of Worcester Cathedral Priory.

\begin{tabular}{|c|c|c|c|c|}
\hline A & B & $\mathrm{B}^{1}$ & $\mathrm{~B}^{2}$ & $C=A / B^{1}$ \\
\hline Jan-Mar 1540 & 1540 & July 1540 & $1543-4$ & $1555-6$ \\
\hline $\begin{array}{l}\text { Battenhall } \\
\text { Berrow } \\
\text { Calaman } \\
\text { Cleeve } \\
\text { Cropthorne } \\
\text { Crowle } \\
\text { Leominster } \\
\text { Newnham } \\
\text { Stourbridge } \\
\text { Sudbury } \\
\text { Wick }\end{array}$ & $\begin{array}{l}\text { Blackwell } \\
\text { Blockley } \\
\text { Bordesley } \\
\text { Grafton } \\
\text { Hodington } \\
\text { Stoke } \\
\text { Bennett } \\
\text { Broadwas } \\
\text { Hanbury } \\
\text { Hardwick } \\
\text { Himbleton } \\
\text { Lawarne } \\
\text { Ledbury } \\
\text { More } \\
\text { Multon } \\
\text { Neckham } \\
\text { Oswald } \\
\text { Shipston } \\
\text { Stanford } \\
\text { Weobley } \\
\text { Wulstan } \\
\text { Wolverley } \\
\text { Gregory } \\
\text { Hallow }\end{array}$ & $\begin{array}{l}\text { Blackwell } \\
\text { Blockley } \\
\text { Bordesley } \\
\text { Grafton } \\
\text { Hodington } \\
\text { Stoke }\end{array}$ & $\begin{array}{l}\text { Bennett } \\
\text { Broadwas } \\
\text { Hanbury } \\
\text { Hardwick } \\
\text { Himbleton } \\
\text { Lawarne } \\
\text { Ledbury } \\
\text { More } \\
\text { Multon } \\
\text { Neckham } \\
\text { Oswald } \\
\text { Shipston } \\
\text { Stanford } \\
\text { Weobley } \\
\text { Wulstan } \\
\text { Wolverley }\end{array}$ & $\begin{array}{l}\text { Calaman } \\
\text { Cleeve } \\
\text { Cropthorne } \\
\text { Crowle } \\
\text { Newnham }\end{array}$ \\
\hline
\end{tabular}

A Ex-monks pensioned in January and March 1540

B Stipendiary priests at Royal College of Worcester in early 1540

B $^{1}$ Ex-monks pensioned in July 1540

B $^{2}$ Personnel of the secular Cathedral in 1543-4

C Ex-monks in receipt of pensions in 1555-6

Table 3. Monks of Worcester pensioned in January 1540.

\begin{tabular}{ll}
\hline Thomas Sudbury & $£ 6.13 \mathrm{~s}$. \\
William Leominster & $£ 6.13 \mathrm{~s}$. \\
Richard Calamon & $£ 6$ \\
John Berrow & $£ 6$ \\
Richard Cleeve & $£ 6$ \\
William Wick & $£ 6$ \\
Thomas Stourbridge & $£ 6$ \\
John Crowle & $£ 6$ \\
Roger Batenhall & $£ 6$ \\
John Cropthorne & $£ 6$ \\
John Newnham & $£ 6$
\end{tabular}

for individual ex-religious, arranged by house, and these include separate documents, all dated 10 March 1540 (31 Henry VIII), for the same eleven men, described as monks of Worcester 'at the time of the dissolution of that place', and arranged in the same order 
Table 4. Monks of Worcester pensioned in July 1540.

\begin{tabular}{ll}
\hline John Blackwell & $£ 10$ \\
William Hodington & $£ 8$ \\
Humphrey Grafton & $£ 8$ \\
Thomas Blockley & $£ 8$ \\
William Bordesley & $£ 13.6 \mathrm{~s} .8 \mathrm{~d}$. \\
Bartholomew Stoke & $£ 10$ \\
\hline
\end{tabular}

as the list above. ${ }^{54}$ The names of these eleven pensioners from January-March 1540 are given as column A in Table 2.

A number of other documents, dating from 10 July 1540, mention pensions being assigned to seven other ex-religious of Worcester. These include the late prior Henry Holbeach, by then also suffragan bishop of Bristol and described here as 'guardian of the late altered monastery of Worcester', who was assigned pensions of variously $£ 240$ and $£ 266.13 \mathrm{~s} .4 \mathrm{~d}$. ${ }^{55}$ Separately however, there are certificates of the same date that describe the pensions of six other individuals said to be monks of Worcester 'at the surrender of that monastery', including William Bordesley who is called steward of the household (Table 4). ${ }^{56}$

The names of the pensioners from July 1540, excluding Holbeach, are given in Table 2 as column $\mathrm{B}^{1}$. It is apparent that these two sets of pension lists - those from January to March 1540 (column A) and those from six months later (column B ${ }^{1}$ ) - are mutually exclusive. The higher and varying amounts of pensions assigned in July 1540 would also suggest some difference between the two groups. Secondly, if we add the names from the two sets of documents together (eleven plus six) we reach a total of seventeen, or eighteen if we include former prior Holbeach, which presumably explains Greatrex's 'seventeen or eighteen' as the size of the Worcester convent at its surrender.

Does this evidence therefore account for the whole monastic community at Worcester as it stood when dissolved in January 1540? I would argue against this conclusion. Firstly, these documents are not deeds of surrender. Furthermore, lists of pensioned ex-religious do not necessarily describe the full membership of a monastery on its surrender because not all monks and canons of dissolved houses received a pension if alternative arrangements had been made, especially in the case of former cathedral priories. Thus, these eighteen pensioned ex-religious of Worcester Cathedral Priory in 1540 need not be the full tally of the monastic community in January of that year.

A separate and hitherto unstudied entry in the Liber Visitationis or Book of Visitation of Bishop John Bell, usually dated 1540, seems to supply the remaining pieces to the puzzle. ${ }^{57}$ This entry forms part of a longer, undated document listing the stipendiary priests of the archdeaconry of Worcester, and is indicated by a marginal heading Collegium Regale Wigorn' (Royal College of Worcester). It comprises a list of twenty-five men, with the forename and surname of each, plus an alias in all but one case, along with the educational status of eight. The surnames and aliases are printed in Table 5 in the order they occur in the manuscript. These names from the Book of Visitation, with the exception of Hugh Colles, are given in Table 2 as column B. The cathedral at Worcester was assigned the status of a royal college

${ }^{54}$ TNA E315/234, fos 239r-241r; LP, XV, p. 551 (no. 1032).

${ }^{5} L P, X V$, nos. 866-67.

${ }^{56} L P, X V$, nos. 868-69.

${ }^{57}$ WRO 802.BA2764, p. 215. 
Table 5. Stipendiary Priests of the Royal College of Worcester, 1540.

\begin{tabular}{|c|c|c|}
\hline magr. Roger Cratford & alias Necham & Doc. Theol. \\
\hline magr. John Pecocke & alias Lawgharn & B.A. Theol. \\
\hline magr. Humphrey Webley & alias Webbe & B.A. Theol. \\
\hline magr. Roger Coke & alias Stanford & B.A. Theol. \\
\hline dns. William Stryff/Scryff & alias Hodington & \\
\hline dns. Humphrey Grafton & alias Fones & \\
\hline dns. John Rowson & alias Multon & \\
\hline dns. William Wilde & alias Hanburie & \\
\hline dns. Thomas Daryngton & alias Blockley & \\
\hline dns. William Sewell & alias Bordesley & \\
\hline dns. Edmund Walker & alias Ledbury & \\
\hline dns. Thomas Hawkes & alias Wolstan & \\
\hline dns. William Marten & alias Benett & \\
\hline dns. Richard Goldsmyth & alias Halow & \\
\hline dns. William Chamber & alias Wolv(er)ley & \\
\hline dns. Nicholas Woddle & alias Shypston & \\
\hline dns. Henry Adams & alias $\mathrm{Hy}(\mathrm{m})$ multon & \\
\hline dns. John Jones & alias Hardwike & \\
\hline dns. Thomas Webbe & alias Oswald & \\
\hline dns. John Jenck(es) & alias Moore & \\
\hline \multicolumn{3}{|l|}{ dns. Hugh Colles } \\
\hline dns. John Penkerich & alias Blackwell & Oxford student \\
\hline dns. Bartholomew Bodoke & alias Stoke & Oxford student \\
\hline$d n s$. Thomas Warham & alias Bradwas & Oxford student \\
\hline dns. Robert Goode & alias Gregorye & Oxford student \\
\hline
\end{tabular}

following the dissolution of the priory probably until it was refounded as a secular cathedral in January $1542 .{ }^{58}$ The entry in Bell's Liber Visitationis is probably a product of this interim period and represents the names of those out-going members of the cathedral priory of 1540 who, in the words of Stanford Lehmberg, 'stayed on, acting as caretakers of the fabric and probably maintaining services as well. ${ }^{59}$ Such an arrangement was not without parallel.

With one exception, the individuals named in this list are supplied with an alias as well as a first surname: only the twenty-first name, Hugh Colles, lacks an alias. Furthermore, and again with the exception of Hugh Colles, all can in fact be readily identified with monks of Worcester in $1534 .{ }^{60}$ In most instances, it is the second surname or 'alias' which was used by the monks in question and which had presumably been adopted on admission to the priory. Thus, 'Roger Cratford, alias Necham' can be identified as Rogerus Nechkam of 1534 and later. Only two individuals in the list can be identified as Worcester monks by their first surname: Humphrey Webley alias Webbe and Humphrey Grafton alias Fones, although the latter does also occur occasionally in priory documents as Fones or Fownys. ${ }^{61}$ The first surnames - or the second for Weobley and Grafton - were probably the hereditary family surnames that had been dropped by the monks on entering the priory. This assumption is supported in the case of Humphrey Weobley whose will, dated 3 June 1551, refers to a brother, called Robert Webbe, as executor, and makes bequests to a number of other relatives surnamed Webbe and Webb. ${ }^{62}$ It was not uncommon both during and after the dissolution

\footnotetext{
${ }^{58}$ MacCulloch, 'Worcester', pp. 100-1.

${ }^{59}$ Lehmberg, p. 83.

${ }^{60}$ Hugh Colles' position in the list, at the end of the main names and before the last four bracketed together separately as Oxford students, also marks him out as distinct.

${ }^{61} B R E C P$, p. 812, where it is pointed out that the form Jones printed in Fegan, p. 50, is an error for Fones.

${ }^{62}$ TNA PROB 11/34/343.
} 
for former religious to either use both their monastic and family surnames ${ }^{63}$ or, in some cases, they revert to using the latter only.

Importantly the list of names in Bell's Liber Visitationis (column B), excluding Hugh Colles, and the list of 11 'superfluous' religious of Worcester from January-March 1540 (column A) do not overlap. The former list appears to record those ex-monks who were, initially at least, retained at the Cathedral, whereas the eleven pensioners were surplus to requirements and were pensioned off. Taken together (columns $\mathrm{A}+\mathrm{B}$ ), the two sets of lists may represent the monastic community of Worcester Cathedral as it stood on the eve of dissolution: thirty-five monks plus Prior Holbeach. Of the forty-one brethren from 1534, we are lacking only six individuals. Hugh Bromsgrove, William More, and John Musard had departed the community well before 1540 . Only three remain unaccounted for: William Fordham, Roger Bewdley and Thomas Grimley. All three were present at the election of Prior Holbeach in March 1536, though both Bewdley and Grimley disappear from the record thereafter and it is possible that they had sought capacities to change habit before 1540, like their erstwhile confreres Hugh Bromsgrove and John Musard. ${ }^{64}$ William Fordham, however, would seem to have chosen an alternative to being pensioned off or receiving a benefice, namely exile abroad. In a document dated March 1546, he is said to have been at Dunfermline Abbey for about six years, 'for refuge and for his faith and the observation of religion', and was accordingly granted the status of 'denizen' of Scotland. ${ }^{65}$ This would suggest he had arrived there in c. 1540 which might imply that he had still been at Worcester when the cathedral priory was surrendered six years earlier but then decided to continue his regular vocation abroad. Fordham's status at Dunfermline Abbey is not entirely clear however: for example, he does not appear among the Dunfermline monks who signed feu charters (leases) dating from both shortly before and after his apparent exile thence. ${ }^{66} \mathrm{On}$ the other hand, Mark Dilworth did point out that the charters and related documents of this period were not necessarily signed by all the members of the relevant Scottish religious houses, so Thomas Fordham may have slipped through the net, perhaps due to his special status. ${ }^{67}$ Either way, Fordham's apparent decision to remain in religion abroad, was exceptional among English ex-religious. ${ }^{68}$ We are left therefore with Prior Holbeach and at least 35 monks to surrender Worcester Cathedral Priory on 16 January 1540, with five members

\footnotetext{
${ }^{63}$ We saw above that, when requesting a capacity in 1538, former Worcester monk John Musard is mentioned in the Faculty Office Register as Musard alias Walker. In an earlier letter to the King, Musard had in fact referred to a kinsman Robert Walker:TNA SP1/95, fo. 48r; LP, IX, p. 52; see also J. G. Clark, 'Why Men Became Monks in Late Medieval England', in Religious Men and Masculine Identity in the Middle Ages, ed. by P. H. Cullum and K. J. Lewis (Woodbridge: Boydell Press, 2013), pp. 160-83, at p. 176.

${ }^{64} B R E C P$, pp. 776,813 . It is doubtful that either Bewdley or Grimley were particularly old by the late 1530 s.

${ }^{65} \mathrm{M}$. Livingstone et al., ed., Registrum Secreti Sigilli Regum Scotorum. The Register of the Privy Seal of Scotland, 8 vols (Edinburgh: H. M. General Register House, 1908-82), III, pp. 254-5 (no. 1599); see also Knowles, Religious Orders, III, p. 345 , n. 1, and $B R E C P$, p. 807.

${ }^{66}$ J. Anderson, ed., Calendar of the Laing Charters, A.D. $854-1837$ (Edinburgh: Edinburgh University Press, 1899), pp. 115 (no. 431), 120-21 (no. 453), 126 (no. 476), 165 (no. 633); C. C. H. Harvey and J. Macleod, ed., Calendar of Writs preserved at Yester House 1166-1625 (Edinburgh: Scottish Record Society, 1930), pp. 179 (no. 618), 189 (no. 661), 192-3 (no. 678). For some unpublished Dunfermline charters, see M. Dilworth, 'Monks and Ministers after 1560', Records of the Scottish Church History Society, 18 (1974), 201-21, at 216.

${ }^{67} \mathrm{M}$. Dilworth, Scottish Monasteries in the Late Middle Ages (Edinburgh: Edinburgh University Press, 1995), p. 50.

${ }^{68}$ David Knowles argued that, with the increasingly localized nature of religious orders in late medieval England, such exile abroad 'would have been all but unthinkable' for most dispossessed religious: Knowles, Religious Orders, III, 412. At least one English Carthusian, Dom William Remington monk of Hull, does seem to have followed Fordham's example and ended his days as guest ('hospes') at the charterhouse at Perth by 1559/60, though he had been in receipt of a pension in England not long before: John Clark, ed., The Villeneuve Necrology, MS. Grande Chartreuse 1 Cart. 22, Analecta Cartusiana, 100/27, 6 vols (Salzburg, 1997-2005), III, p. 133. Most other ex-religious who wished to remain in religion moved to the Continent.
} 


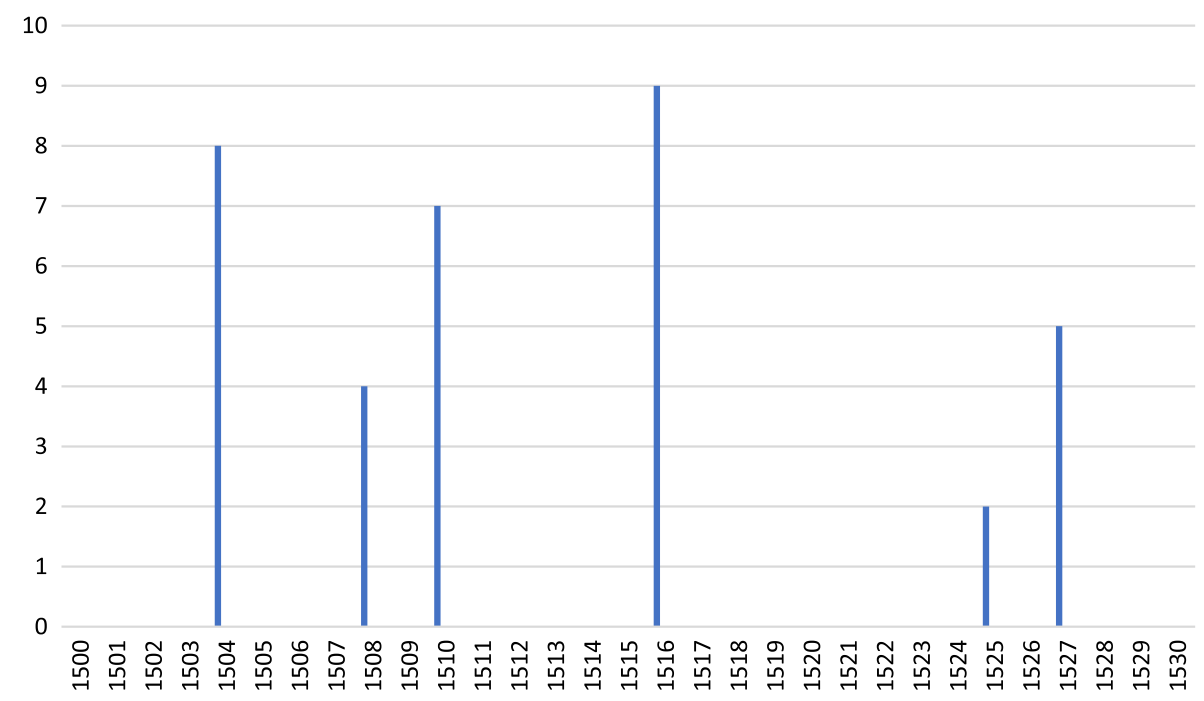

Graph 1. Monks of Worcester Ordained Acolyte, 1500-30.

of the community of forty-one that took the oath of supremacy in 1534 having departed before 1540, and one other seeking to continue in his regular vocation north of the border.

The decline in the size of the priory's cathedral chapter between 1534 and 1540 can be explained partly in terms of the departure of a handful of monks during the intervening five- and-a-half years. Such a loss of members, however, was neither new nor unique in the late 1530s. Older brethren had always passed away and needed to be replaced, as did those who had opted to transfer to another religious house. Between 1521 and 1530 five monks of Worcester had been granted permission by their prior to move to another house, an average of one every two years. ${ }^{69}$ What is significant in the second half of the $1530 \mathrm{~s}$ is that no new monks appear to have been admitted to make up the loss. Analysis of the ordination of Worcester monks as acolytes during the first three decades of the sixteenth century in Chart 1 shows that new monks were not ordained individually, year by year, but were usually ordained in groups: we have already noted the significance of one such cohort (1504), including Thomas Fordham, Roger Neckham and John Musard, as later opponents of Prior More.

The periodic admission of small groups of postulants, and therefore their subsequent ordination in groups, rather than a constant stream of individuals, was common during the late middle ages, especially among larger religious houses. ${ }^{70}$ In such instances, the size of the monastic community was likely to fluctuate a little over time, as some monks died or transferred without being replaced immediately, thus reducing the size, or when a new group of monks was admitted, thus increasing the size. Could the decline in the size of the Worcester Cathedral convent between 1534 and 1540 simply have been the product of a similar ongoing fluctuation, which would have righted itself had Henry VIII and Cromwell

\footnotetext{
${ }^{69}$ WCL Reg. A.6(ii), fos 139v, 143v, 157r, 158r, 169r. See also, J. Greatrex,'Prosopographical Perspectives, or What can be done with Five Thousand Monastic Biographies?', Medieval Prosopography, 20 (1999), 129-45, at 134-5.

${ }^{70}$ For example, J. G. Greatrex, The English Benedictine Cathedral Priories: Rule and Practice, c. 1270-1420 (Oxford: Oxford University Press, 2011), pp. 37-8; B. F. Harvey, Living and Dying in England, 1100-1540. The Monastic Experience (Oxford: Oxford University Press/Clarendon Press, 1993), pp. 73-4.
} 
not dissolved the priory in 1540 ? This is uncertain because five and a half years without any apparent new admissions and ordination does seem rather long. Chart 1 shows two significant gaps between the ordination of acolytes: six years between 1510 and 1516, and nine between 1516 and 1525, when a mere two monks were ordained acolyte. The latter can be shown to be the result of a number of lacunae in the extant ordination records in the episcopal registers of Worcester between 1517 and $1526 .{ }^{71}$ Other evidence indicates that nine new monks had joined the priory before July 1521 for whom no record of ordination as acolyte survives. ${ }^{72}$ If the previous trend of admission and ordination as acolyte had continued unabated, then we might expect evidence of a few new monks at least between August 1534 and January 1540. However, the general injunction issued by the royal government as part of the visitations of monasteries in 1535-6 that 'no man be suffered to profess or to wear the habit of religion in this house, e're he be 24 years of age compleat ${ }^{73}$ would, if strictly enforced, have reduced the number of younger novices entering religious houses, including Worcester Cathedral Priory. After some debate, Cromwell and his commissioners decided to enforce this injunction for future professions only: those existing regulars who had been professed under twenty four were not to be invalidated, and those who were still under twenty four could either remain in religion if they wished or choose to leave. ${ }^{74}$ These decisions would certainly have affected the ability of religious houses to replace departed brethren, and may therefore account for the decline in recruitment at Worcester. Other factors may have been the turbulent atmosphere at the Cathedral Priory during the mid-1530s as well as the growing storm outside the cloister from 1536 onwards that, within a few short years, would lead to the complete disappearance of monastic life in England and Wales.

The story of the last monks of Worcester did not stop in January 1540. Nor, however, did it come to an end with the formal establishment of the secular cathedral two years later. A letter patent dated 13 January 1542, 'reconstructing the late monastery of the cathedral church of St. Mary, Worcester, as a cathedral of one dean and ten prebendaries', names the senior personnel of the new cathedral: as occurred at many other refoundations, it was the prior (Holbeach) who was appointed as dean, and we also find four of his erstwhile brethren - Roger Neckham, John Laughern, Roger Stanford and Humphrey Weobley - among the prebends or major canons. ${ }^{75}$ These four are also listed as major canons with an annual stipend of $£ 20$ assigned to each in a document preserved in Worcester Cathedral Library

\footnotetext{
${ }^{71}$ See my paper 'How Useful are Episcopal Ordination Lists as a Source for Medieval English Monastic History?' Journal of Ecclesiastical History (forthcoming, 2018). Furthermore, the two monks who become acolyte in 1525 John Blackwell and Nicholas Shipston were in fact ordained by the bishop of Hereford: Bannister, p. 320.

${ }^{72}$ Lambeth Palace Library, Reg. of Archbishop Warham, vol. II, fo. 293v. Eight of the nine in question were among those who acknowledged the oath of supremacy in 1534: Ralph (recte Thomas?) Oswald, Thomas Wolstan, William Bennett, Thomas Grimley, Hugh Bromsgrove, John Crowle, Roger Battenhall, and Richard Hallow. The last name in the 1521 list, William More, was probably not the prior of that name, as there is also the record of ordination as deacon of a William More in 1525: Bannister, p. 321. Nor can this be an error for the later John More, as he was ordained subdeacon in 1533: WRO b706.093-BA2648/7(ii), p. 174.

${ }^{73}$ D. Wilkins, Concilia Magnae Britanniae et Hiberniae, 4 vols (London: R. Gosling, 1737), III, p. 791.

${ }^{74}$ Logan, pp. 160-2.

${ }^{75} \mathrm{LP}$, XVII, no. 71/28; see also J. Le Neve and J. M Horn, ed., Fasti Ecclesiae Anglicanae 1541-1857: Volume 7, Ely, Norwich, Westminster and Worcester Dioceses (London: University of London, Institute for Historical Research, 1992), pp. 125-30. Note that prebendary Richard Liste/Lisle should not be identified as Richard Hallow whose family surname was clearly Goldsmith: contra B. Willis, A Survey of the Cathedrals of York, Durham, Carlisle, Chester, Man, Litchfield, Hereford, Worcester, Gloucester, Bristol, Lincoln, Ely, Oxford, Peterborough, Canterbury, Rochester, London, Winchester, Chichester, Norwich, Salisbury, Wells, Exeter, St. Davids, Landaff, Bangor, and St. Asaph (London: R. Gosling, 1742), II, p. 679; Noake, The Monastery, p. 528; BRECP, pp. 814-15.
} 
describing the financial arrangements for the new cathedral in 1543-4. ${ }^{76}$ The same document also names ten minor canons ('subcanonicorum siue subprebendariorum') with $£ 10$ each per annum, all of whom had been monks at Worcester in 1534: John Multon, William Bennett, William Wolverley, Nicholas Shipston, John Hardwick, Thomas Broadwas, Thomas Wotton (recte Wolston?), Thomas Oswald, William Hanbury and Henry Himbleton. Finally, this list of minor canons is followed by an account for Edward (sic) Ledbury as Evangelii Cantor or 'Gospeller' (deacon) and John More as Epistole Cantor or 'Epistoler' (subdeacon), who received an annual salary of $£ 8$. If Wotton is corrected to Wolston and Edward to Edmund (both understandable scribal or editorial misreadings), then we have here in 1543-4, sixteen of the twenty-five individuals named in the list in Bell's Liber a few years earlier. These sixteen names are given in Table 2 as column $\mathrm{B}^{2}$.

The names in columns $\mathrm{B}^{1}$ and $\mathrm{B}^{2}$ do not overlap: the ex-monks pensioned in July 1540 were not among those sixteen listed as personnel of the secular cathedral in 1543-4. Furthermore, if $\mathrm{B}^{1}$ and $\mathrm{B}^{2}$ are added together, they equate to the so-called caretakers named in Bell's Book of Visitations (column B), minus two names (Gregory and Hallow). It is possible therefore that Bell's list (B) is a very early account of the royal college's personnel in the first weeks after the dissolution of the priory and, in turn, that within a few months, a further six ex-monks had departed with pensions $\left(\mathrm{B}^{1}\right)$. The remaining ex-monks went on to form the personnel of the secular cathedral in 1542 and are listed as such in 1543-4 $\left(\mathrm{B}^{2}\right)$. The fate of Robert Gregory and Richard Hallow is not clear: as they do not appear to be named as pensioners; perhaps they continued at the 'college' in 1540-2 but departed some time before 1543-4.

Tracing the later fortunes of the last monks of Worcester is a detailed task beyond the scope of this paper, but a few comments may be ventured, based upon a survey of the evidence. Firstly, it is likely that a few of the older members of the former convent of St Mary's did not live long after the events described here. Among the ex-monks who received pensions in 1540 were William Hodington, Humphrey Grafton and William Leominster. Hodington had been ordained in the early 1480s and the other two less than a decade later: this would possibly make Hodington around eighty years old when the priory was dissolved, and Grafton and Leominster well in their seventies. ${ }^{77}$ Comparing the dates of death known for a handful of former Worcester monks who held ecclesiastical positions later on with the dates of their ordination, most would seem to have passed away in their sixties, with a few living into their seventies. Of the new cathedral's prebendaries, Dr Neckham was perhaps in his mid-seventies when he died in 1558, and Roger Stanford had probably not been much younger when he passed away in 1550. Their fellow canons, John Laughern and Humphrey Weobley, both died in 1551, possibly in their early sixties.

On the other hand, we know that some of the pensioned former brethren of Worcester Priory lived at least until the reign of Queen Mary and a handful were still in receipt of pensions during that of Elizabeth. Thus, a survey of pensions and other payments in 1555/6 (Table 6) associated with Cardinal Pole records the pensions of nine ex-monks. ${ }^{78}$ These nine

\footnotetext{
${ }^{76}$ Printed at Leach, pp. 158-9.

${ }^{77}$ These age estimates are based upon the assumption that monks were about 20 when admitted and first ordained.

${ }^{78}$ TNA E164/31; BL Add. MS 8102; Dugdale, I, p. 581. Note also Willis, Mitred Abbies, p. 312, which gives similar list, dated ' 1553 ', and rearranged according to value of pension, thus assigning Cleeve, Cropthorne, Crowle and Newnham $£ 5$ each. In addition, we might note that among those listed separately in 1555/6 in receipt of an annuity, worth $£ 6.13$ s.4d, was one Roger Necham, who may be identified as ex-monk Dr Roger Neckham, alias Cratford, who was a canon at Worcester from 1542 until his death in 1558.
} 
Table 6. Monks of Worcester Pensioned in 1555/6.

\begin{tabular}{ll}
\hline Richard Coleman & $£ 6$ \\
Richard Cleave & $£ 6$ \\
Bartholomew Stoke [Stow in BL MS] & $£ 10$ \\
Thomas Blakeley & $£ 8$ \\
William Bordesley & $£ 13.6 \mathrm{~s} .8 \mathrm{~d}$ \\
John Newman & $£ 6$ \\
John Cropthorne & $£ 6$ \\
John Crowell & $£ 6$ \\
John Blakewall [Barkewall in BL MS] & $£ 10$ \\
\hline
\end{tabular}

names are given in Table 2 as column $\mathrm{C}$ and comprise five of the monks deemed superfluous and pensioned in January 1540 (from column A) plus four of those initially retained at the royal college but pensioned off in July of the same year (from column $\mathrm{B}^{1}$ ). The pension amounts here were the same as those first assigned over a decade and a half earlier. In addition, three of these nine, Bartholomew Bowdocke (Stoke), John Cropthorne and John Crowle (Crowell), are recorded among the ex-monks and ex-cantarists of Worcestershire who paid tax on their pensions in $1576-8 .^{79}$

In addition to the positions held by former brethren of Worcester as part of the new cathedral chapter, a number of ex-monks are recorded in episcopal and cathedral registers as receiving ecclesiastical livings elsewhere. ${ }^{80}$ There is evidence, not without parallel, ${ }^{81}$ that some of the ex-religious personnel of the new cathedral were able to acquire livings which were among the spiritualities granted to the dean and chapter in $1542 .{ }^{82}$ Thus, the dean and chapter possessed the rectory and advowson of the vicarage at Cropthorne, Worcestershire, where ex-Worcester monk and later prebend Humphrey Weobley (alias Webbe), ${ }^{83}$ was rector from 1544, and vicar on his death in 1551. He was also briefly perpetual vicar of Old Sodbury, Gloucestershire, in 1546-7, where the cathedral chapter held the rectory and advowson. ${ }^{84}$ Weobley was succeeded at Cropthorne by his former confrere Thomas Wolston (alias Hawkes) ${ }^{85}$ who held it until 1557 when he himself passed away. In 1550, William Wolverley, ${ }^{86}$ minor canon in 1542, was instituted rector of Worcester St Clement's, of which the chapter held the advowson, and in 1557 until his death the following year, he was perpetual vicar of Worcester St Peter's, also controlled by the chapter. At St Clement's, he seems to have been succeeded by one William Paynter and thereafter (1563-73) by another former religious, William Compton, probably ex-monk of Pershore. At St Peter's, his immediate successor as vicar was his old confrere Thomas Broadwas, ${ }^{87}$ also minor canon in 1542, until his own demise in 1565. Similarly, in 1544 Dr Roger Neckham, prebend, was instituted as rector of another advowson of the new cathedral, Worcester St Swithun's, which

\footnotetext{
${ }^{79}$ TNA E179/363/358, fos. 5v, 6v, and 8r. I am very grateful to Dr. Maureen Jurkowski for bringing this material to my attention and facilitating access to the relevant folios; see also her article 'The History of Clerical Taxation in England and Wales, 1173-1663: The Findings of the E 179 Project', Journal of Ecclesiastical History, 67/1 (2016), 53-81, at 76, n. 113.

${ }^{80}$ Especially useful here is the CCEd: Clergy of the Church of England Database 1540-1835, for which see http://theclergydatabase.org.uk/. I will cite individuals from this database below according to their CCEd Person IDs.

${ }^{81}$ Baskerville, 'The Dispossessed Religious', 452-3.

${ }^{82} L P, \mathrm{XVII}$, no. $71 / 29$. Most of the lands and churches granted to the new secular cathedral chapter had previously been in possession of the priory.

${ }^{83}$ CCEd Person ID 83174; WCL Reg. A.7(i), fo. 69r.

${ }^{84}$ WCL Reg. A.7(i), fo. 89r.

${ }^{85}$ CCEd Person ID 83107; WCL Reg. A.7(ii), fo.24v.

${ }^{86}$ CCEd Person ID 83105.

${ }^{87}$ CCEd Person ID 66491; WCL Reg. A.7(ii), fo. 32r.
} 
he held until resigning in $1555 .{ }^{88}$ Neckham was also rector of Worcester St Martin's until his death in 1558, and was succeeded by his former monastic colleague, William Bennet (alias Martine) ${ }^{89}$ minor canon in 1542, who continued as rector until his own passing in 1573. Furthermore, in 1542 the dean and chapter were assigned the rectory and advowson of the vicarage of Sedgebarrow, where we find John Laughern, ${ }^{90}$ as rector from 1544 until his death in 1551; and, in 1544, William Hanbury alias Wilde was instituted as perpetual vicar at Dodderhill, where the dean and chapter also held the rectory and advowson. ${ }^{91}$

A number of other ex-monks of Worcester can also be found in the cathedral and episcopal registers holding benefices in the diocese. Among those who occur in bishop Bell's manuscript as priests at the Royal College of Worcester in 1540 but pensioned off by July was John Penkridge alias Blackwell who may be the John Blackwell, rector of Belbroughton on his death in December $1558 .{ }^{92}$ Outside the diocese, Dominus (Dom) Thomas Blockley ${ }^{93}$ who was perpetual vicar of Bosbury, Herefordshire, between 1547 and 1559, may be identified as ex-monk Thomas Darington alias Blockley. Among those monks deemed superfluous in January 1540, one John Cropthorne was curate of Sedgebarrow in $1550,{ }^{94}$ and John Newenham alias Wright was rector at Bredicot from 1544 to $1562 .{ }^{95}$ Finally, the dean and chapter also had the rectory and advowson of vicarage of Wolverley, where a 'Dom. John Crowle alias Yewes (Hughes?) was perpetual vicar from 1546; ${ }^{96}$ and from 1555 to 1558 the same man (Johannes Croll, alias Ewes) was vicar at Tibberton where the chapter held the advowson. ${ }^{97}$ This individual may be ex-Worcester monk John Crowle. Less convincingly, a Dom John More was instituted rector of Great Comberton, Worcestershire, in 1545 until his death in $1586 .{ }^{98}$ Blackwell, Blockley, Cropthorne, and Crowle were all in receipt of pensions in 1555-6, and Cropthorne and Crowle were in 1576-8.

Ex-prior Henry Holbeach appears to have promoted a number of his former Worcester brethren during his subsequent career. Holbeach stepped down as dean of Worcester Cathedral in May 1544, on his elevation to the see of Rochester. He was bishop of Rochester until 1547, when he was in turn translated to Lincoln. He died in $1551 .{ }^{99}$ Despite these career moves, Holbeach does not appear to have lost contact with his old church and brethren on moving to Rochester: between 1544-7, he was the vicar of Bromsgrove, where the dean and chapter had the rectory and advowson for the vicarage; and furthermore, a handful of ex-monks of Worcester were appointed to benefices in both of his dioceses. Thus, Nicholas Shipston, minor canon at Worcester in 1543-4, was made a minor canon at Rochester Cathedral between December 1545 and July 1546 at least. ${ }^{100}$ In addition, one Bartholomew Bowdocke (or Bodocke), ${ }^{101}$ who may be the ex-monk Bartholomew Stoke, alias Bodocke,

\footnotetext{
${ }^{88}$ CCEd Person ID 82647; WCL Reg. A.7(i), fo. 63r; Reg. A7(ii), fo.13r.

${ }^{89}$ CCEd Person ID 66484; WCL Reg. A.7(ii), fo. 33v.

${ }^{90} \mathrm{CCEd}$ Person ID 81846; WCL Reg. A.7(i), fo. 47v.

${ }^{91}$ CCEd Person ID 82153; WCL Reg. A.7(i), fo. 67v.

${ }^{92}$ CCEd Person ID 79592.

${ }^{93}$ CCEd Person ID 169437.

${ }^{94}$ CCEd Person ID 25634. A Dom John Cropthorne was curate at Pershore St Andrew in 1563, and at Avon Dassett, Warws., in 1573: CCEd Person ID 25634. We know that the former monk of the same names was still alive in 1578.

${ }^{95}$ CCEd Person ID 45026; WCL Reg. A.7(i), fo. 62r.

${ }^{96}$ CCEd Person ID 79981.

${ }^{97} \mathrm{WCL}$, Reg. A.7(i), fos. 9, 34r. It is not clear whether John Croll died or resigned, as there is a blank space in the manuscript at this point.

${ }^{98}$ CCEd Person ID 66554; for his will see TNA PROB 11/70/125.

${ }^{99}$ Bowker, 'Holbeach'.

${ }^{100}$ CCEd Person ID 3102.

${ }^{101}$ CCEd Person ID 2183 and 2189.
} 
was perpetual vicar of Frindsbury, Kent, within the diocese of Rochester, from August 1544, a few months after Holbeach's translation until 1554 and, he was also presented to the vicarage of Gedney, Lincs., in 1550. As Bowdocke, he was still in receipt of a pension in 1576-8.

This paper argues that the monastic chapter of St Mary's Cathedral Priory numbered at least thirty-five monks plus the prior when it was dissolved in January 1540, that is, more than previous estimates. Of the forty-one brethren who acknowledged the oath of supremacy in the summer of 1534, we know of the certain departure of only three, including the old prior who was replaced by an outsider. Two other monks remain unaccounted for after March 1536, and may have left the community before 1540. Finally, one monk chose to continue his monastic vocation in Scotland, though whether he was present at the surrender of the priory or had departed north of the border beforehand is unknown. The Worcester convent appears only to have acquired one new member during the period 1534-40, and that was the new prior, Henry Holbeach. A decrease in size from forty-one brethren in 1534 to thirty-six in 1540 represents a 12 per cent decline which, it has been argued, was a result not only of the handful of departures prior to 1540 but also of an evident interruption in the periodic admission of new recruits that had prevailed before the second half of the 1530s. Following the surrender of the priory, about two-thirds of the priory's brethren were initially kept on at the temporary 'royal college', though a number of these were pensioned off within six months, and less than half of the former monks of Worcester were retained when the new cathedral of secular canons was eventually founded in January 1542. Of course, as a cathedral priory, the situation at Worcester was a little different from that of those religious houses whose monastic buildings were simply sold off after the dissolution and whose former brethren were sent out into the world. However, it does seem likely that the ecclesiastical revolution initiated in England and Wales in 1534 did indeed have a negative impact upon the size of the Benedictine community at Worcester before its final dissolution in January 1540, and we should expect similar evidence for other monasteries.

\section{Disclosure statement}

No potential conflict of interest was reported by the author.

\section{Notes on Contributor}

A native of North Wales, Dr. David E. Thornton is an historian of the British Isles during the Middle Ages who lectures in European History at Bilkent University, Turkey. His research has encompassed Wales and Ireland in the early medieval period and AngloNorman England, with special reference to Domesday Book. He is currently working on a prosopographical study of the monastic orders in England c. 1300 until the Dissolution, focusing on religious houses in the medieval Diocese of Worcester. Dr. Thornton plays rock guitar and mountain dulcimer.

\section{ORCID}

David E. Thornton (D) http://orcid.org/0000-0001-8977-0690 